7. Reprod. Fert. (1967) 13, 101-119

\title{
A NEW DERIVATIVE OF TRIPHENYLETHYLENE: EFFECT ON IMPLANTATION AND MODE OF ACTION IN RATS
}

\author{
M. J. K. HARPER AND A. L. WALPOLE \\ Imperial Chemical Industries Limited, Pharmaceuticals Division, \\ Alderley Park, Macclesfield, Cheshire
}

(Received 19th March 1966)

\begin{abstract}
Summary. I.C.I. 46,474 , the trans-isomer of $1-(p$ - $\beta$-dimethylaminoethoxyphenyl-1,2-diphenylbut-l-ene, is very effective in terminating early pregnancy by preventing implantation when given during the first 4 days after insemination to female rats. In this species, the compound is weakly and atypically oestrogenic and is also anti-oestrogenic, as indicated by its inhibitory effect on the response to exogenous oestrogens of the vaginal epithelium (cornification) and uterus (weight-increase). It is suggested that it can prevent implantation in rats by virtue of its anti-oestrogenic activity, i.e. by counteracting the oestrogen-release from the ovaries which is believed to occur on the 4th day and upon which implantation appears to depend.

The corresponding cis-isomer (I.C.I. 47,699) is very different in its properties and behaves in all respects like a conventional oestrogen (orally active - e.g. dienoestrol). In rats it is very much more potent as an oestrogen than I.C.I. 46,474-by which its uterotrophic action is inhibited. On the other hand the trans-isomer is the more potent of the two in inducing vaginal cornification in ovariectomized mice.
\end{abstract}

\section{INTRODUGTION}

Clomiphene, 1-(p-diethylaminoethoxyphenyl)-1,2-diphenyl-2-chloroethylene (citrate), a basic ether related to the oestrogen triphenylchloroethylene (Robson, Schönberg \& Fahim, 1938) was first described by Holtkamp, Greslin, Root \& Lerner (1960) as an anti-fecundity agent in female rats with an inhibitory action on pituitary gonadotrophic function, weak uterotrophic activity and some oestrogen-antagonizing effect.

More recently, compounds of two series have been described which may be regarded as basic ethers of 'cyclized' triphenylethylenes. These are represented, respectively, by the diphenylindene 2-[ $p$-(6-methoxy-2-phenylinden-3-yl)phenoxy] triethylamine hydrochloride (U-11555A), and the diphenyldihydronaphthalene, 1-(2-[ $p$-\{3,4-dihydro-6-methoxy-2-phenyl-1-naphthyl)phenoxy] ethyl) pyrrolidine hydrochloride (U-11100A). Both the former (Duncan, Stucki, Lyster \& Lednicer, 1962) and the latter of these substances (Duncan, 
Lyster, Clark \& Lednicer, 1963) have marked anti-fertility effects in female animals of several species. In rats U-11100A is the more potent, a single oral dose of $0.25 \mathrm{mg} / \mathrm{kg}$, given within 4 days of insemination, being sufficient to inhibit pregnancy. These compounds are not markedly inhibitory of pituitary gonadotrophic activity and are only weakly uterotrophic but they have demonstrable anti-oestrogenic properties. There is evidence (Duncan \& Lyster, 1963; Duncan \& Forbes, 1965) that their capacity to terminate early pregnancy in rats is due to inhibition of the oestrogen-dependent mechanism of implantation -i.e. is a manifestation of their anti-oestrogenic action.

During the past 5 years a series of compounds has been synthesized in these laboratories (Richardson, 1965) which have affinities in chemical structure both with clomiphene and with the indene and dihydronaphthalene derivatives referred to above. In general they may be represented by the formulae:

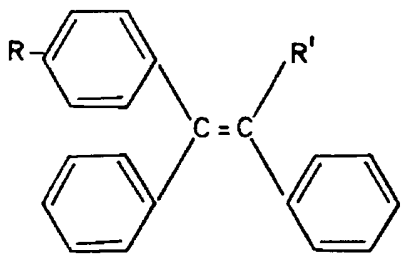

cis-I somer

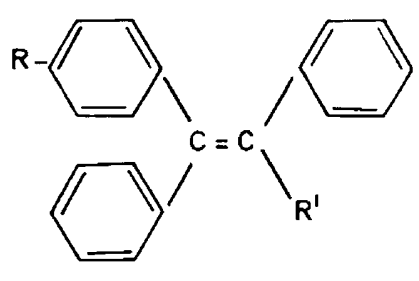

trans - Isomer

where $\mathrm{R}$ is a basic ether grouping and $\mathrm{R}^{\prime}$ a lower alkyl radical, each compound existing in two stereo-isomeric forms according to the relative disposition, cis or trans, of the unsubstituted phenyl nuclei. The mixture of isomers in which $\mathbf{R}$ is dimethylaminoethoxy and $\mathbf{R}^{\prime}$ ethyl has been separated into its cis-(I.C.I. 47,699) and trans-(I.C.I. 46,474) components. The trans-isomer, given by mouth, has proved to be very potent in inhibiting nidation in rats, and in this species is a weak and atypical oestrogen with anti-oestrogenic properties and little pituitary-inhibitory activity. By contrast, the cis-isomer has the properties of a conventional oestrogen. Detailed biological studies of I.C.I. 46,474 and a comparison of its properties with those of the cis-isomer are described in this paper.

\section{MATERIALS AND METHODS}

The rats and mice, used in these studies, were from the random mated colonies of specific pathogen-free animals maintained at Alderley Park. Both were albinos of strains designated Alderley Park Strain I.

I.C.I. 46,474 and 47,699 , the trans- and cis-isomers, respectively, of 1- $(p-\beta-$ dimethylaminoethoxyphenyl)-1,2-diphenylbut-1-ene, were used as the citrates. These were made up as dispersions by ball-milling for $16 \mathrm{hr}$ in $0.5 \%$ aqueous Tween 80 . Stock dispersions were stored in the dark at $5^{\circ} \mathrm{C}$ and diluted for use as required.

The reference-substances used were: dienoestrol, similarly made up in aqueous dispersion, and oestradiol- $17 \beta$ and testosterone propionate, dissolved in arachis oil and given subcutaneously. SKF 525-A ( $\beta$-diethylaminoethyldiphenylpropyl acetate $\mathrm{HCl}$ ), dissolved in distilled water immediately before use, was injected intraperitoneally. 
The experimental procedures used for the routine assessment of biological activity are described below. Unless stated otherwise, I.C.I. 46,474 and 47,699 and dienoestrol were administered by gavage.

\section{INHIBITION OF IMPLANTATION}

In rats

Female rats in pro-oestrus were housed overnight with fertile males. Those which on the following morning (Day 1-first day of pregnancy) had cornified vaginal smears containing spermatozoa were dosed on various days before the expected time of implantation and killed on Day 8. At autopsy the numbers of corpora lutea and implantation sites were counted and compared.

\section{In mice}

Mature male and female mice were paired (Day 0), dosed on Days 3 to 7 inclusive and killed on Day 13. At autopsy the numbers of implantation sites were recorded.

\section{OESTROGENIC ACTIVITY}

In rats

By vaginal cornification. Unprimed adult female rats, ovariectomized about 14 days before the experiment, were dosed daily for 3 days (Days 1 to 3 ). Vaginal smears were taken each morning from Days 1 to 5 inclusive, and also in the late afternoon of Day 4. Smears were classified as cornified which were composed of cornified and/or nucleated epithelial cells with no more than the occasional leucocyte. The median cornifying dose was calculated from the proportion of rats which had a cornified smear at any time during the last 3 days of test.

By uterine weight-increase. Intact immature female rats, 35 to $50 \mathrm{~g}$ in body weight, were dosed daily with the test-substance for 3 days and on the 4th day were killed and their uteri excised, blotted and weighed. The increase in mean uterine weight/100 $\mathrm{g}$ (final) body weight over that of controls, given only dispersing medium, was used as an index of uterotrophic effect.

\section{In mice}

By vaginal cornification. Ovariectomized mature female mice were primed with oestrone, $1 \mu \mathrm{g} / \mathrm{mouse}$, s.c., 7 days before use. They were then dosed daily for 3 days with the test-substance and vaginal smears taken on the morning and afternoon of the 4th day and, in some tests, on the morning of the 5th day. The median cornifying dose was calculated from the proportion of all the smears examined, at each level of dosage, which contained only cornified cells.

\section{ANTI-OESTROGENIC ACTIVITY}

In rats

By inhibition of oestrogen-induced vaginal cornification. Unprimed mature female rats, ovariectomized about 14 days before use, were dosed once daily for 7 days with oestradiol, $0 \cdot 25 \mu \mathrm{g} / \mathrm{rat}$ s.c. and graded doses of I.C.I. 46,474 by gavage. 
Vaginal smears were examined daily from the 1st to 8th day of experiment. Control animals, receiving the oestradiol only, had cornified smears from the 4 th to 8 th day inclusive. The appearance, during this time, of leucocytes in the smears from animals given I.C.I. 46,474 also was taken as an index of its anti-oestrogenic effect.

By inhibition of oestrogen-induced increase in uterine weight. Intact immature rats ( 35 to $50 \mathrm{~g}$ ) were given three daily doses of oestradiol, 0.5 or $5.0 \mu \mathrm{g} / \mathrm{rat}$, s.c., together with graded doses of I.C.I. 46,474 or 47,699 by gavage. The rats were killed and their uteri weighed on the 4th day and these weights were corrected for (final) body weight. The inhibition of uterine growth compared with the growth produced by oestradiol alone in control animals was used as a measure of anti-oestrogenic effect.

A similar test was also carried out in immature rats, ovariectomized on the day before the 1st day of dosing.

\section{In rats}

\section{INHIBITION OF PITUITARY GONADOTROPHIC FUNCTION}

Male rats (about $100 \mathrm{~g}$ in body weight) were given graded doses-nine in 10 days - of the substance under test. Reductions in weight, per $100 \mathrm{~g}$ final body weight, of the accessory sex organs at autopsy on the 11 th day provided an indirect measure of inhibition of pituitary gonadotrophic activity.

Immature female rats, 30 days old, were maintained for 3 weeks on a diet containing $0.04 \%$ I.C.I. 33,828 (Paget, Walpole \& Richardson, 1961). This prevented the onset of puberty and ovulation. At the end of this time I.C.I. 33,828 was withdrawn and replaced with the test-substance or vehicle alone to controls, given daily for the next 7 days. The animals were killed on the day after the last day of dosing and at autopsy the numbers of corpora lutea in the ovaries and the weights of the latter were recorded. A reduction in these parameters in the rats treated with the test-substance was taken as evidence of its pituitary-inhibitory effect.

\section{In rabbits}

Mature rabbit does in oestrus $(3.7$ to $4.8 \mathrm{~kg})$ were given a single dose of I.C.I. 46,474. About $24 \mathrm{hr}$ later they were mated with vigorous males. The females were killed about $18 \mathrm{hr}$ after mating, and the ovaries examined for the presence of ovulation points.

\section{ANDROGENIC EFFECTS IN RATS}

These were assessed indirectly by evidence of stimulation of accessory sex organs in the male rats used for the test on pituitary inhibition (see above).

\section{ANTI-ANDROGENIC EFFECTS IN RATS}

Immature male rats ( 23 to 25 days old) were castrated and treated daily for 7 days with testosterone propionate $(25 \mu \mathrm{g} / \mathrm{rat} /$ day s.c.) either alone or with I.C.I. 46,474 (by gavage) at various dose levels. Controls received arachis oil 
only, s.c. At autopsy on the 8th day the ventral prostate and seminal vesicles were weighed.

\section{EFFECTS ON THE OESTROUS CYCLE OF THE RAT}

Three groups of eleven normally cycling female rats were fed on diets containing $0,0.0001$ or $0.001 \%$ of I.C.I. 46,474 for 3 weeks, the daily intake of the compound in the latter two groups being about $0 \cdot 1$ and $1 \mathrm{mg} / \mathrm{kg} /$ day respectively. Vaginal smears were examined daily starting 1 week before treatment and continuing for 2 weeks after treatment.

\section{ACUTE LETHALITY FOR MICE}

$\mathrm{LD}_{50}$ were calculated from the numbers of deaths during the 14 days after dosing in groups of five female mice (about $30 \mathrm{~g}$ ) given single graded doses of I.C.I. 46,474 by mouth or intraperitoneally.

\section{EFFECTS ON CHOLESTEROL BIOSYNTHESIS}

I.C.I. 46,474 was given in the diet at levels of $0,0.002$ and $0.01 \%$ to young adult male and female rats (body weight about $150 \mathrm{~g}$ and $125 \mathrm{~g}$ respectively) for 11 days. The non-saponifiable fractions of the serum and liver, taken at autopsy on the 12th day, were analysed for cholesterol and desmosterol by a combination of methods (Abell, Levy, Brodie \& Kendall, 1952; Connerty, Briggs \& Eaton, 1961; Avigan, Steinberg, Vroman, Thompson \& Mosettig, 1960). In order to allow for small variations in the occurrence of desmosterol in control animals and for differences in the colour-yields between series of estimations, the results of these measurements were expressed as a ratio of the desmosterol present in the samples from the treated groups to that in the samples from the simultaneous controls. When desmosterol constituted $5 \%$ of the total sterols in the treated animals, this ratio was found to average +4 . This has been taken as an arbitrary upper limit in assessing the acceptability of compounds which cause desmosterol accumulation by blocking cholesterol synthesis.

\section{STATISTICAL METHODS}

Median effective doses were calculated by the simplified method of Litchfield \& Wilcoxon (1949), and the significance of difference between mean values was tested by Duncan's method (1955).

\section{RESULTS}

In rats

\section{INHIBITION OF IMPLANTATION}

The daily dose of I.C.I. 46,474 and 47,699, given orally on Days 2, 3 and 4 of pregnancy, required to prevent implantation of $50 \%$ of the ova shed, i.e. the median effective dose (MED) anti-implantation (AI) - is shown in Table 1. It 
can be seen that I.C.I. 46,474 is significantly more active than its cis-isomer, and of the same order of activity as dienoestrol (an orally active oestrogen).

To determine on which day I.C.I. 46,474 is most effective, single oral doses were given on different days of pregnancy before implantation, and the respective meDs calculated (Table 1). It is clear that the compound is most effective when given on Day 4. Similar experiments were performed with dienoestrol (Table 1). In contrast to I.C.I. 46,474, the effectiveness of this reaches a maximum on Day 3, and progressively declines on Days 4 and 5. Implantation can, however, still be prevented by an appropriate dose on Day 5. This is not the case with I.C.I. 46,474 .

Since I.C.I. 46,474 is very effective when given in a single oral dose on any

\section{TABLE 1}

PREVENTION OF IMPLANTATION IN RATS BY I.C.I. 46,474, 47,699 OR DIENOESTROL GIVEN ORALLY WITHIN THE FIRST 5 DAYS OF PREGNANCY

\begin{tabular}{|c|c|c|c|c|c|}
\hline $\begin{array}{c}\text { Day (s) of } \\
\text { dosing }\end{array}$ & $\begin{array}{c}\text { I.C.I. } 46,474 * \\
\text { MED } \\
\text { (mg/kg/day) }\end{array}$ & $\begin{array}{c}\mathrm{P} \\
\text { differ- } \\
\text { ence }\end{array}$ & $\begin{array}{c}\text { I.C.I. 47,699* } \\
\text { MED } \\
(\mathrm{mg} / \mathrm{kg} / \mathrm{day})\end{array}$ & $\begin{array}{c}\text { Dienoestrol } \\
\text { MED } \\
\text { (mg/kg/day) }\end{array}$ & $\begin{array}{c}\mathrm{P} \\
\text { differ- } \\
\text { ence }\end{array}$ \\
\hline 2 to 4 & $0.030(0.027$ to 0.035$) \dagger$ & & $0.280(0.230$ to 0.342$) \dagger$ & $0.024(0.009$ to 0.067$) \dagger$ & \\
\hline $\begin{array}{l}1 \\
2 \\
3 \\
4 \text { a.m. } \\
4 \text { p.m. } \\
5\end{array}$ & $\begin{array}{l}0.38(0.34 \text { to } 0.42) \\
0.20(0.17 \text { to } 0.22) \\
0.15(0.14 \text { to } 0.16) \\
0.12(0.10 \text { to } 0.14) \\
0.12(0.10 \text { to } 0.13) \\
20 \mathrm{mg} / \mathrm{kg} \text { inactive }\end{array}$ & $\begin{array}{l}<0.05 \\
<0.05 \\
<0.05\end{array}$ & & $\begin{array}{l}0.05(0.04 \text { to } 0.05) \\
0.05(0.04 \text { to } 0.06) \\
0.04(0.03 \text { to } 0.04) \\
0.15(0.08 \text { to } 0.28) \\
0.38(0.33 \text { to } 0.43)\end{array}$ & $\begin{array}{l}<0.05 \\
<0.05 \\
<0.05\end{array}$ \\
\hline $\begin{array}{c}\text { Total rats } \\
\text { used }\end{array}$ & 311 & & 14 & 176 & \\
\hline
\end{tabular}

* Throughout this study these compounds were given as the citrates and, unless stated otherwise, all dosages are expressed in these terms.

$\uparrow$ Figures in parentheses are the $95 \%$ confidence limits.

of the first 4 days of pregnancy, intermittent dosing would be expected to prevent the development of pregnancy indefinitely in female rats housed continuously with males. To test this hypothesis groups of twelve females were caged with males (four females and one male/cage) and given various doses of I.C.I. 46,474 by mouth, once or twice a week. A control group of twelve females was caged with vasectomized males and dosed with the vehicle twice a week. Vaginal smears were taken 5 days a week from all females. From the number of smears with spermatozoa in the treated groups and from the incidence of prolonged periods of di-oestrus in the control group (indicating pseudopregnancy) an estimate of frequency of mating was obtained. Higher doses of the compound were found to reduce mating-frequency. The results of this experiment are shown in Table 2. It appears that a dose of $0.25 \mathrm{mg} / \mathrm{kg}$ given orally twice a week is sufficient to prevent pregnancy for at least 12 weeks. The reduction in the frequency of mating with this dose is not significant, and where it occurs it is presumably due to failure of the treated rats to experience full 
physiological oestrus. This is examined further in the section 'Effects on the oestrous cycle of the female rat' (p. 115).

In mice

When mature female mice, paired with fertile males on Day 0 , and killed on Day 13, were orally dosed with I.C.I. 46,474 on Days 3 to 7 inclusive, implantation was completely prevented by $1 \mathrm{mg} / \mathrm{kg} /$ day or more. The MED was 0.35

TABLE 2

\begin{tabular}{|c|c|c|c|c|c|c|}
\hline \multicolumn{2}{|c|}{ Dosage } & \multirow{2}{*}{$\begin{array}{c}\text { Duration } \\
\text { of } \\
\text { dosing } \\
\text { (weeks) }\end{array}$} & \multirow{2}{*}{$\begin{array}{c}\text { Smears } \\
\text { taken } \\
\text { (weeks) }\end{array}$} & \multirow{2}{*}{$\begin{array}{l}\text { Frequency } \\
\text { of mating } \\
\text { (per week) }\end{array}$} & \multicolumn{2}{|c|}{ Pregnancies } \\
\hline $\begin{array}{c}\text { Level } \\
(\mathrm{mg} / \mathrm{kg})\end{array}$ & $\begin{array}{l}\text { Frequency } \\
\text { per week }\end{array}$ & & & & No. & Litter sizes \\
\hline $\begin{array}{l}0 \dagger \\
0 \cdot 25 \\
0 \cdot 5 \\
1 \cdot 0 \\
0 \cdot 5 \\
1 \cdot 0\end{array}$ & $\begin{array}{l}2 * \\
2 \\
2 \\
2 \\
1 \\
1\end{array}$ & $\begin{array}{r}12 \\
12 \\
12 \\
12 \\
6 \\
6\end{array}$ & $\begin{array}{r}12 \\
12 \\
9 \\
9 \\
6 \\
6\end{array}$ & $\begin{array}{l}3 \cdot 0 \\
2 \cdot 6_{\ddagger}^{+} \\
2 \cdot 7 \\
1 \cdot 7 \\
2 \cdot 8 \\
2 \cdot 2\end{array}$ & $\begin{array}{l}\overline{0} \\
0 \\
0 \\
2 \\
2\end{array}$ & $\begin{array}{l}- \\
- \\
- \\
- \\
6,5 \\
3,1\end{array}$ \\
\hline
\end{tabular}

* Dosed with vehicle only.

$\uparrow$ Control group caged with vasectomized males.

$\ddagger$ Only eleven rats in this group (mating frequency given = mating frequency observed $\times 12 / 11$ ).

TABLE 3 PREVENTION BY I.C.I. 46,474 GIVEN ORALLY OF
IMPLANTATION IN MIGE

\begin{tabular}{|c|c|c|c|}
\hline \multirow{2}{*}{$\begin{array}{c}\text { Dose } \\
(\mathrm{mg} / \mathrm{kg} / \text { day })\end{array}$} & \multicolumn{2}{|c|}{ No. of mice } & \multirow{2}{*}{$\begin{array}{c}\text { Implantations/pregnant mouse } \\
\text { Mean } \pm \text { S.E. }\end{array}$} \\
\hline & Total & Pregnant & \\
\hline $\begin{array}{l}0 \\
0 \cdot 1 \\
0 \cdot 25 \\
0 \cdot 5 \\
1 \cdot 0 \\
10 \cdot 0\end{array}$ & $\begin{array}{l}20 \\
10 \\
20 \\
20 \\
20 \\
10\end{array}$ & $\begin{array}{r}15(75 \%) \\
9(90 \%) \\
13(65 \%) \\
8(40 \%) \\
0 \\
0\end{array}$ & $\begin{array}{c}10 \cdot 7 \pm 1 \cdot 0 \\
10 \cdot 8 \pm 1 \cdot 2 \\
8 \cdot 4 \pm 0 \cdot 7 \\
8 \cdot 4 \pm 1 \cdot 4 \\
0 \\
0\end{array}$ \\
\hline
\end{tabular}

$(0.24$ to 0.51$) \mathrm{mg} / \mathrm{kg} /$ day (Table 3$)$. In those of the treated mice which became pregnant at any dosage level, the mean number of implantations was not significantly different from the control figure.

\section{In rats}

\section{OESTROGENIC ACTIVITY}

Vaginal cornification. As determined by our procedure, the median cornifying doses (MCD) of I.C.I. 46,474, I.C.I. 47,699 and dienoestrol in rats are as shown in Table 4 . With the conventional oestrogen, dienoestrol, an anti-fertility effect 
is produced only at a dose greater than that which causes vaginal cornification. The same is true of I.C.I. 47,699, but the reverse situation obtains with I.C.I. 46,474 . With this latter compound, vaginal cornification is produced with only very large doses relative to those affecting implantation. In rats, therefore, I.C.I. 46,474 does not behave like a conventional oestrogen.

Uterine weight-increase. The increase in weight of the uterus produced by a substance in immature rats can also be used as an index of oestrogenic activity. The dose-response curves for I.C.I. 46,474 and I.C.I. 47,699 respectively, compared with that for oestradiol-17 $\beta$ are shown in Text-fig. 1. Oestradiol has

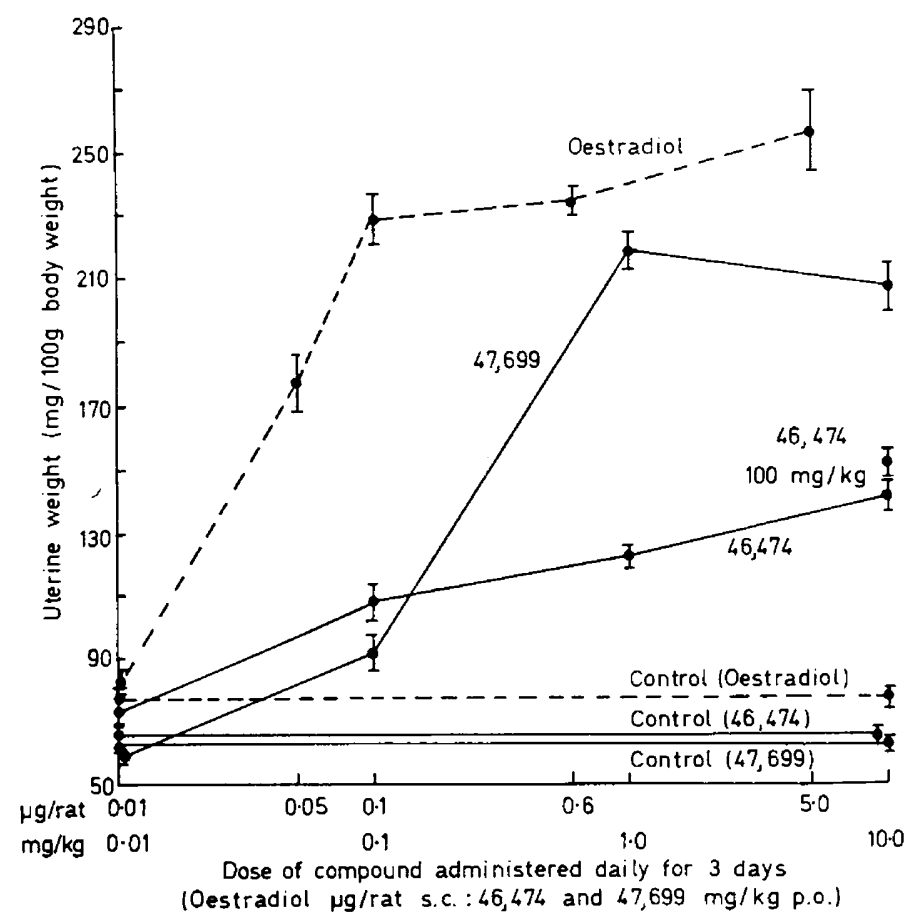

TEXT-FIG. 1. Effect of I.C.I. 46,474, I.C.I. 47,699 and of oestradiol-17 $\beta$ on uterine weight in immature female rats.

no effect at $0.01 \mu \mathrm{g} / \mathrm{rat} /$ day and its effect is maximal at $0.1 \mu \mathrm{g} / \mathrm{rat} /$ day. I.C.I. 46,474 , given orally, produces a much flatter dose-response curve; it causes a significant response at $0.1 \mathrm{mg} / \mathrm{kg} /$ day, but has to be given at $10 \mathrm{mg} / \mathrm{kg} / \mathrm{day}$ to produce a maximal effect. Moreover, the uterine weight reached with the latter dose is only about half the maximum obtained with oestradiol. I.C.I. 47,699 behaves like a conventional oestrogen, giving a dose-response curve of similar form to oestradiol.

\section{In mice}

Vaginal cornification. Groups of ten ovariectomized mice were given graded doses of I.C.I. 46,474 or I.C.I. 47,699 by mouth once daily for 3 days. In the first test with I.C.I. 46,474 vaginal smears were taken only on the morning and evening of the 4th day after commencing dosing. In all subsequent tests, however, smears were also taken on the morning of the 5th day, because of the 
delayed response in cornification. There was no significant difference in the MCD found for I.C.I. 46,474 in three different tests-1.40 (0.98 to 2.00), 1.20 $(0.67$ to 2.16$)$ and $1.64(1.09$ to 2.46$) \mathrm{mg} / \mathrm{kg} /$ day, nor in that for I.G.I. 47,699 in two tests-7.5 (4.5 to 12.4$)$ and $6.4(4.5$ to 9.1$) \mathrm{mg} / \mathrm{kg} /$ day. (Figures in parentheses are $95 \%$ confidence limits.)

It is clear that in mice, in contrast to rats (Table 4), I.C.I. 46,474 is far more oestrogenic than its cis-isomer. In case the increased oestrogenicity of I.C.I. 46,474 in mice was due to stimulation of oestrogen production by the adrenal, a test was carried out in adrenalectomized, ovariectomized mice. The MCD $1.55(0.96$ to 2.51$) \mathrm{mg} / \mathrm{kg} /$ day was unaltered by this change in procedure.

TABLE 4

OESTROGENIC POTENCY OF I.C.I. 46,474, I.C.I. 47,699 AND DIENOESTROL (GIVEN FOR 3 DAYS) IN OVARIECTOMIZED RATS

\begin{tabular}{|c|c|c|c|c|c|}
\hline $\begin{array}{c}\text { Route of } \\
\text { administration }\end{array}$ & Compound & $\begin{array}{l}\text { Total rats } \\
\quad \text { used }\end{array}$ & $\begin{array}{c}\text { MCD } \\
(m g / k g / d a y)\end{array}$ & $95 \%$ confidence limits & $\underset{\mathrm{MCD} / \mathrm{MED}_{\mathrm{AI}}}{\text { Ratio }}$ \\
\hline Oral (p.o.) & $\begin{array}{c}\text { I.C.I. 46,474 } \\
\text { I.C.I. 47,699 } \\
\text { Dienoestrol }\end{array}$ & $\begin{array}{l}18 \\
42 \\
24\end{array}$ & $\begin{array}{l}41 \cdot 0 \\
0 \cdot 18 \\
0 \cdot 004\end{array}$ & $\begin{array}{l}27.7 \text { to } 60.7 \\
0.12 \text { to } 0.25 \\
0.002 \text { to } 0.007\end{array}$ & $\begin{array}{r}1355 \\
0 \cdot 6 \\
0 \cdot 2\end{array}$ \\
\hline s.c. & $\begin{array}{l}\text { I.C.I. } 46,474 \\
\text { I.C.I. } 47,699\end{array}$ & $\begin{array}{l}18 \\
30\end{array}$ & $\begin{array}{c}18 \cdot 0 \\
0 \cdot 30\end{array}$ & $\begin{array}{l}9.9 \text { to } 32.8 \\
0.20 \text { to } 0.46\end{array}$ & \\
\hline
\end{tabular}

* See Table 1 .

A further possibility, i.e. that I.C.I. 46,474 is a pro-oestrogen in mice, was investigated by determining its MCD by intra-vaginal application in this species. (The procedure was otherwise identical with that using oral dosing.) The value found, $0.35(0.17$ to 0.73$) \mathrm{mg} / \mathrm{kg} /$ day, gives a ratio between intra-vaginal and oral potency of 3 to 5 and thus, according to Emmens (1941), the compound would be classified as a pro-oestrogen. Metabolism to the true oestrogen might well involve removal of the basic side chain and, since SKF 525-A has been shown to inhibit enzyme systems which could bring this about (Cooper, Axelrod \& Brodie, 1954), it was of interest to determine if SKF 525-A would affect the apparent oestrogenic potency of the compound.

Daily oral doses of $0.25,0.5,1.0$ and $2.5 \mathrm{mg} / \mathrm{kg}$ I.C.I. 46,474 were given to each of two groups of ten ovariectomized mice with or without $1 \mathrm{mg} / \mathrm{mouse}$ i.p. of SKF 525-A twice daily. At no level of dosage was a significant difference found between the incidence of cornified smears in the two groups. Thus degradation of the basic side-chain would not seem to be involved in the conversion of I.C.I. 46,474 to a true oestrogen.

\section{ANTI-OESTROGENIC ACTIVITY}

In rats

Inhibition of oestrogen-induced vaginal cornification. In doses much below those required to induce vaginal cornification, I.C.I. 46,474 inhibits the vaginal response to oestradiol in ovariectomized rats. Control animals, given the oestradiol only, showed cornified smears from the 4 th to the 8 th day inclusive. 
The proportion of animals, treated with I.C.I. 46,474 also, having leucocytes in the smear on any day during this period, is shown in Table 5. Also shown are the total numbers of smears from each group of rats which contained leucocytes during the same period. A dose of $0.0125 \mathrm{mg} / \mathrm{kg} /$ day I.C.I. 46,474 has no effect, while complete inhibition is produced by $1 \mathrm{mg} / \mathrm{kg} /$ day.

TABLE 5

INHIBITION BY I.C.I. 46,474 OF VAGINAL CORNIFICATION INDUCED BY OESTRADIOL IN OVARIEGTOMIZED RATS; THE RATS WERE DOSED DAILY (DAYS 1 TO 7 INCLUSIVE) WITH OESTRADIOL $(0 \cdot 25 \mu \mathrm{g} /$ RAT S.C.) AND

I.C.I. 46,474 IN THE DOSES SHOWN, BY MOUTH

\begin{tabular}{c|c|c}
\hline \multirow{2}{*}{$\begin{array}{c}\text { Dose of } \\
\text { I.C.I. } 46,474\end{array}$} & Data from vaginal smears (one/day) on Days 4 to 8 inclusive \\
\cline { 2 - 3 } & $\begin{array}{c}\text { Rats with leucocytes } \\
\text { in smear/rats in group }\end{array}$ & $\begin{array}{c}\text { Smears with leucocytes/ } \\
\text { total smears in group }\end{array}$ \\
\hline 0 & $0 / 6(0 \%)$ & $0 / 30(0 \%)$ \\
$0 \cdot 0125$ & $0 / 6(0 \%)$ & $0 / 30(0 \%)$ \\
0.05 & $4 / 12(33 \%)$ & $9 / 60(15 \%)$ \\
0.2 & $11 / 12(92 \%)$ & $42 / 60(70 \%)$ \\
1.0 & $6 / 6(100 \%)$ & $30 / 30(100 \%)$ \\
\hline
\end{tabular}

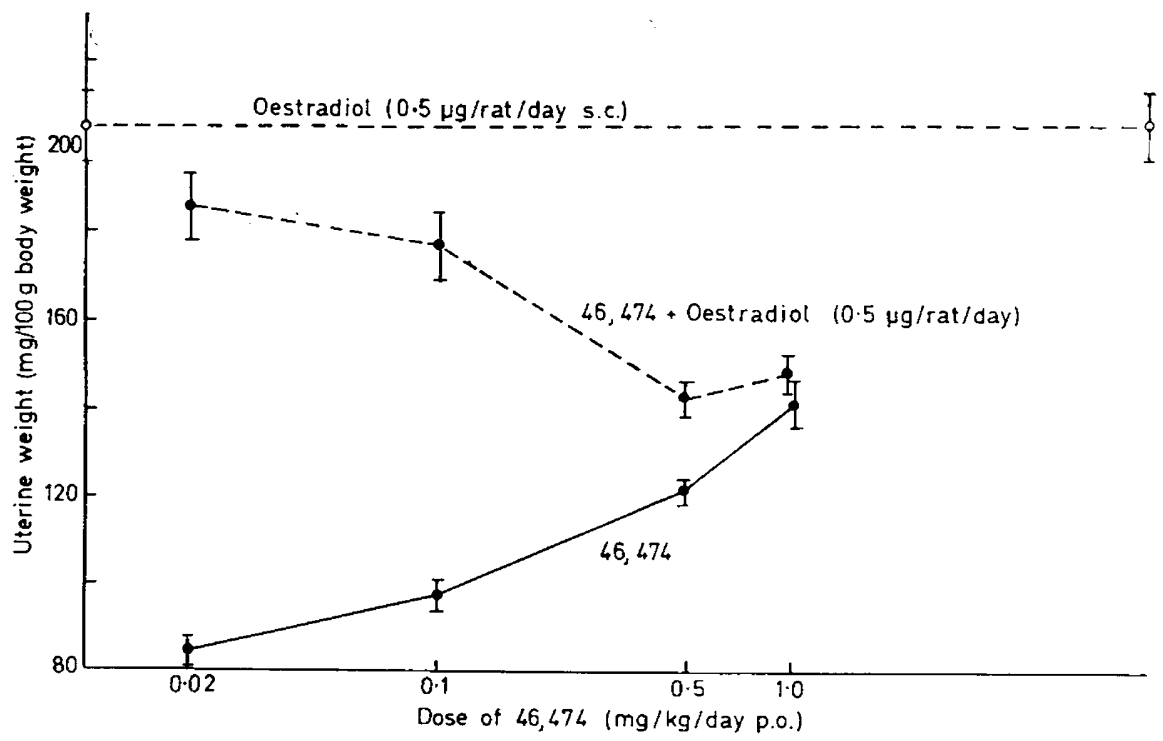

Text-FIG. 2. Effect of I.C.I. 46,474 and of oestradiol-178 on uterine weight in immature female rats.

Inhibition of oestrogen-induced increase in uterine weight. From Text-fig. 2 it appears that the uterine weight-increase produced by $0.5 \mu \mathrm{g} / \mathrm{rat} / \mathrm{day}$ of oestradiol is progressively reduced by increasing doses of I.C.I. 46,474, and is completely abolished by $1 \mathrm{mg} / \mathrm{kg} / \mathrm{day}$ of the latter. The response to $5 \mu \mathrm{g} / \mathrm{rat} /$ day of oestradiol is abolished by a dose of $2.0 \mathrm{mg} / \mathrm{kg} /$ day I.C.I. 46,474 (Text-fig. 3). In a further experiment it was shown that I.C.I. 47,699 would not inhibit the uterotrophic 
action of oestradiol (Text-fig. 4). Since I.C.I. 47,699 behaves like a conventional oestrogen, while the trans-isomer has anti-oestrogenic properties, two experiments were carried out to determine whether I.C.I. 46,474 would prevent the

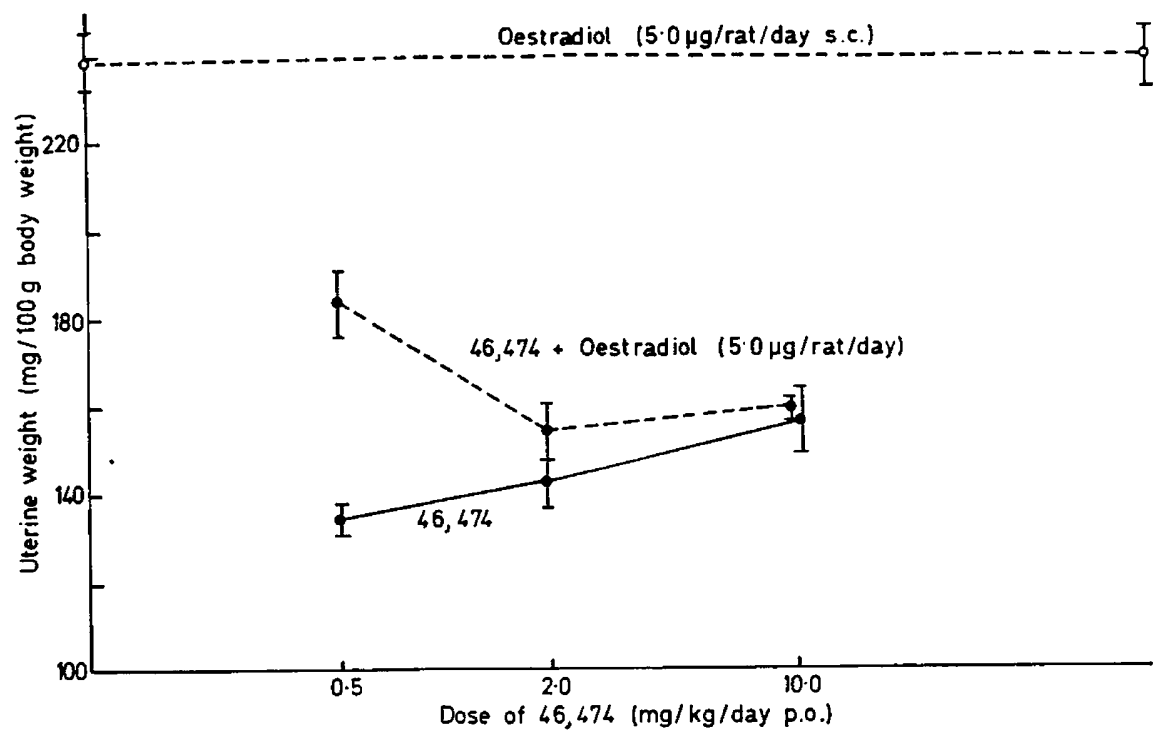

TEXT-FIG. 3. Effect of I.C.I. 46,474 and of oestradiol-17 $\beta$ on uterine weight in immature female rats.

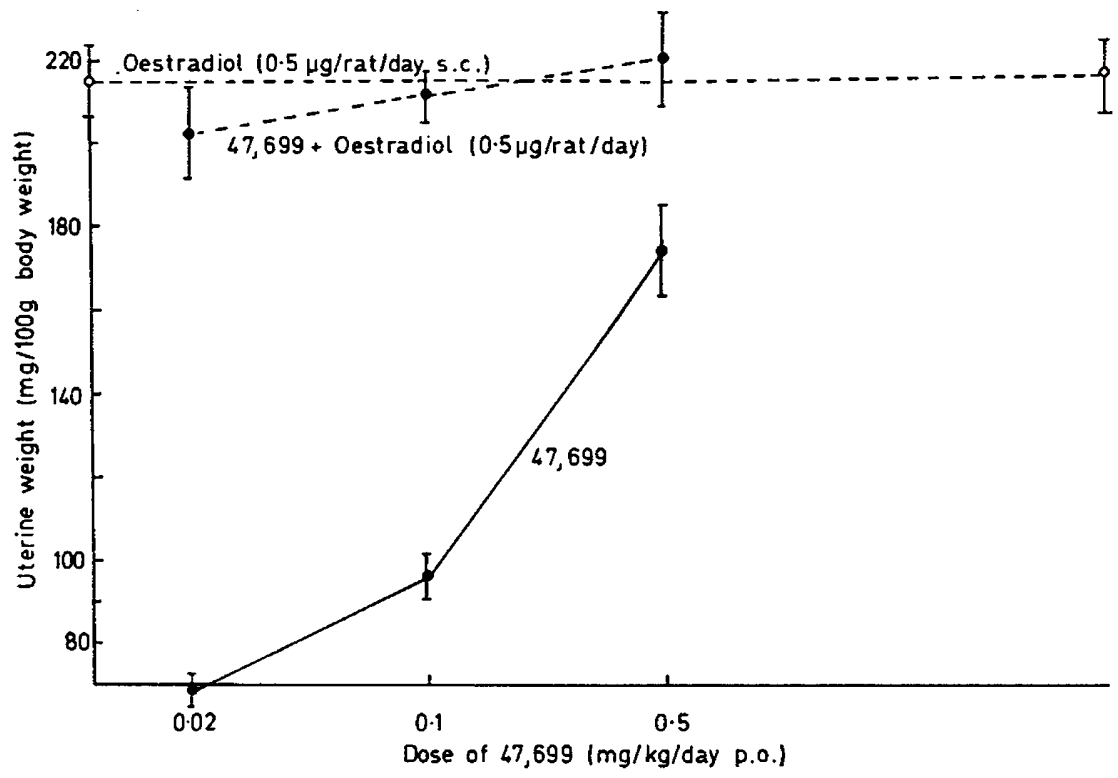

TEXT-FiG. 4. Effect of I.C.I. 47,699 and of oestradiol-17 $\beta$ on uterine weight in immature female rats.

uterotrophic effects of the cis-isomer. Text-fig. 5 shows that the uterotrophic effect of $2.0 \mathrm{mg} / \mathrm{kg} /$ day I.C.I. 47,699 is progressively reduced by increasing doses of I.C.I. 46,474 , and is completely abolished by $2.0 \mathrm{mg} / \mathrm{kg} /$ day. Indeed, 
it seems likely that a dose of $1 \mathrm{mg} / \mathrm{kg} /$ day would have been fully effective. When the dose of I.C.I. 47,699 was increased to $20 \mathrm{mg} / \mathrm{kg} /$ day, its effects were blocked by $10 \mathrm{mg} / \mathrm{kg} /$ day I.C.I. 46,474 . Thus it appears that I.C.I. 46,474 consistently abolishes the uterotrophic effect of twice the dose of its cis-isomer. It is remarkable that the oestrogenic action of one isomer can be blocked by the other.

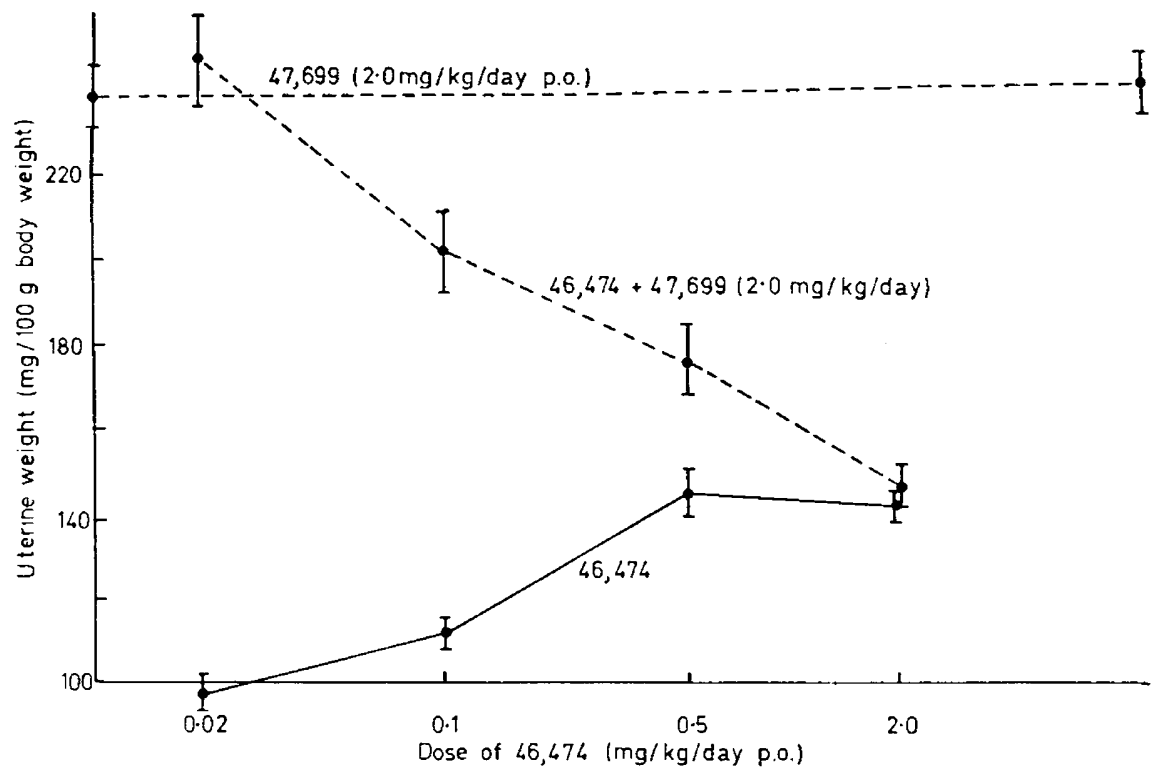

TEXT-FIG. 5. Effect of I.C.I. 46,474 and its oestrogenic isomer I.C.I. 47,699 on uterine weight in immature female rats.

\section{Male rats}

INHIBITION OF PITUITARY GONADOTROPHIC FUNCTION

In daily doses up to $5 \mathrm{mg} / \mathrm{kg}$, I.C.I. 46,474 had only small and variable effects on the relative weight of the ventral prostate and seminal vesicles in intact male rats (Table 6). A dose of $25 \mathrm{mg} / \mathrm{kg} /$ day caused a significant and maximal depression in seminal vesicle weight and $100 \mathrm{mg} / \mathrm{kg} /$ day was needed for a marked effect upon the prostate. The largest reductions in weight of these organs were less than those obtained with conventional oestrogens. Progressively increased doses of I.C.I. 46,474 caused a corresponding increase in the relative testicular weight. However, the absolute weight of the testes was not significantly affected. The compound caused an increase in the relative and absolute weights of the adrenals, the maximum adrenal weights observed being similar to those normally seen in female rats of similar size, and also a progressive reduction in the increase in body weight over the period of the test.

A similar test was performed with the oestrogenic isomer (Table 7). Even a dose of $0.5 \mathrm{mg} / \mathrm{kg} /$ day caused a reduction in seminal vesicle weight, and maximal depression of both ventral prostate and seminal vesicle weight were produced with a daily dose of $2.5 \mathrm{mg} / \mathrm{kg}$. A maximal increase in adrenal weight and reduction in body weight increase was also produced at this dose. 
Testes weight was decreased only at the highest dose level $(12.5 \mathrm{mg} / \mathrm{kg} /$ day $)$. In this test I.C.I. 47,699 behaves like a conventional oestrogen. It was found that a daily dose of $0.01 \mathrm{mg} / \mathrm{kg}$ dienoestrol produced a $22 \%$ and $42 \%$ decrease in ventral prostate and seminal vesicle weights respectively.

\section{Female rats}

The incidence of ovulation was studied in immature female rats after I.C.I. 33,828 had been withdrawn from the diet and replaced by graded oral doses of I.C.I. 46,474. Complete inhibition of ovulation was observed at a daily dose

TABLE 6

EFFECTS OF I.C.I. 46,474 ON THE RELATIVE WEIGHTS OF THE ACGESSORY GLANDS AND OTHER ORGANS IN INTAGT MALE RATS (SIX RATS/TREATED GROUP: TWELVE RATS IN CONTROL GROUP)

\begin{tabular}{c|c|c|c|c|c|c}
\hline & \multicolumn{6}{|c}{ Percentage change from control in: } \\
$\begin{array}{c}\text { Dose } \\
\left(\begin{array}{l}\text { mg/kg/day } \\
\text { p.o. })\end{array}\right.\end{array}$ & $\begin{array}{c}\text { Ventral } \\
\text { prostate }\end{array}$ & $\begin{array}{c}\text { Seminal } \\
\text { vesicles }\end{array}$ & Testes & Adrenals & Thyroid & $\begin{array}{c}\text { Body weight } \\
\text { increase }\end{array}$ \\
\hline $0 \cdot 2$ & 7 & 0 & 11 & 7 & 10 & -31 \\
$1 \cdot 0$ & -11 & -14 & 18 & 15 & 12 & -42 \\
$5 \cdot 0$ & 13 & -2 & 17 & 5 & 5 & -55 \\
$25 \cdot 0$ & -16 & -41 & 21 & 16 & 5 & -66 \\
$100 \cdot 0$ & -26 & -39 & 30 & 45 & 6 & -82 \\
\hline
\end{tabular}

TABLE 7

EFFECTS OF I.C.I. 47,699 ON THE RELATIVE WEIGHTS OF THE ACCESSORY GLANDS AND OTHER ORGANS IN INTAGT MALE RATS (SIX RATS/TREATMENT GROUP: TWELVE RATS/GONTROL GROUP)

\begin{tabular}{c|c|c|c|c|c|c}
\hline & \multicolumn{6}{|c}{ Percentage change from controls in: } \\
$\begin{array}{c}\text { Dose } \\
\left(\begin{array}{c}\text { mg/kg/day } \\
\text { p.o. })\end{array}\right.\end{array}$ & $\begin{array}{c}\text { Ventral } \\
\text { prostate }\end{array}$ & $\begin{array}{c}\text { Seminal } \\
\text { vesicles }\end{array}$ & Testes & Adrenals & Thyroid & $\begin{array}{c}\text { Body weight } \\
\text { increase }\end{array}$ \\
\hline 0.5 & -7 & -31 & 28 & 20 & 6 & -48 \\
$2 \cdot 5$ & -66 & -64 & -6 & 63 & 36 & -85 \\
12.5 & -70 & -63 & -25 & 68 & 29 & -96 \\
\hline
\end{tabular}

of $1 \mathrm{mg} / \mathrm{kg}$, while the MED (ovulation inhibited in $50 \%$ of rats) was found to be $0.25(0.17$ to 0.37$) \mathrm{mg} / \mathrm{kg} /$ day (Table 8$)$.

Ovarian weight decreased progressively as the dose of I.C.I. 46,474 was increased. Significant decreases from the control level were observed only with doses of 0.5 and $1.0 \mathrm{mg} / \mathrm{kg} /$ day. In rats that ovulated, however, normal numbers of corpora lutea were found.

The results with I.C.I. 47,699 are shown in Table 9. It is clear that this compound is very ineffective in preventing ovulation. The best effect $(67 \%$ inhibition) was produced by a daily dose of $10 \mathrm{mg} / \mathrm{kg}$, and less by $20 \mathrm{mg} / \mathrm{kg} / \mathrm{day}$. No MED could be calculated from these results, but it is obviously greater than $1 \mathrm{mg} / \mathrm{kg} /$ day. Ovarian weight was significantly lower than control for all treatment groups. 
A daily oral dose of $0.1 \mathrm{mg} / \mathrm{kg}$ of dienoestrol inhibited ovulation in three out of six rats in a similar test situation, but increased doses up to $4 \mathrm{mg} / \mathrm{kg} /$ day had no greater effect. Conventional oestrogens are relatively ineffective in inhibiting ovulation in this test, and I.C.I. 47,699 is no exception.

\section{Female rabbits}

Out of six rabbits dosed by mouth with $1 \mathrm{mg} / \mathrm{kg}$ of I.C.I. 46,474, five mated. At autopsy $18 \mathrm{hr}$ later, all five were found to have ovulated, the mean number of ovulations/rabbit being $8.6 \pm 0 \cdot 6$ (S.E.). This figure is within the normal

TABLE 8

INHIBITION OF OVULATION IN PUBERAL RATS BY I.C.I. 46,474

\begin{tabular}{|c|c|c|c|c|}
\hline \multirow{2}{*}{$\begin{array}{c}\text { Dose } \\
(m g / k g / d a y \\
\text { p.o.) }\end{array}$} & \multicolumn{2}{|c|}{ Rats } & \multirow{2}{*}{$\begin{array}{l}\text { Corpora lutea } \\
\text { |rat ovulating } \\
\text { Mean } \pm S . E .\end{array}$} & \multirow{2}{*}{$\begin{array}{c}\text { Ovarian weight } \\
\text { (mg) } \\
\text { Mean } \pm S . E .\end{array}$} \\
\hline & Treated & Ovulating & & \\
\hline $\begin{array}{l}0 \\
0 \cdot 125 \\
0 \cdot 25 \\
0 \cdot 5 \\
1 \cdot 0\end{array}$ & $\begin{array}{l}24 \\
12 \\
12 \\
12 \\
12\end{array}$ & $\begin{array}{c}23(96 \%) \\
11(92 \%) \\
6(50 \%) \\
1(8 \%) \\
0\end{array}$ & $\begin{array}{l}8 \cdot 3 \pm 0.5 \\
7 \cdot 0 \pm 0.6 \\
8 \cdot 8 \pm 0.4 \\
10 \cdot 0 \\
-\end{array}$ & $\begin{array}{l}29 \cdot 7 \pm 1 \cdot 3 \\
27 \cdot 5 \pm 1 \cdot 6 \\
26 \cdot 0 \pm 2 \cdot 0 \\
21 \cdot 1 \pm 1 \cdot 4 * \\
20 \cdot 0 \pm 0 \cdot 7 *\end{array}$ \\
\hline
\end{tabular}

* Significantly different from control.

TABLE 9

INHIBITION OF OVULATION IN PUBERAL RATS BY I.C.I. 47,699

\begin{tabular}{c|c|c|c|c}
\hline $\begin{array}{c}\text { Dose } \\
\left(\begin{array}{c}\text { mg/kg/day } \\
\text { p.o. })\end{array}\right.\end{array}$ & \multicolumn{2}{|c|}{ Rats } & $\begin{array}{c}\text { Corpora lutea } \\
\text { Irat ovulating } \\
\text { Mean } \pm \text { S.E. }\end{array}$ & $\begin{array}{c}\text { Ovarian weight } \\
\text { (mg) } \\
\text { Mean } \pm S . E .\end{array}$ \\
\cline { 2 - 4 } & Treated & Ovulating & & \\
\hline 0 & 14 & $14(100 \%)$ & $8 \cdot 4 \pm 0 \cdot 4$ & $31 \cdot 7 \pm 1 \cdot 3$ \\
$0 \cdot 1$ & 6 & $6(100 \%)$ & $6 \cdot 3 \pm 0 \cdot 6$ & $24 \cdot 5 \pm 2 \cdot 4^{*}$ \\
$1 \cdot 0$ & 6 & $6(100 \%)$ & $6 \cdot 0 \pm 0 \cdot 7$ & $23 \cdot 6 \pm 1 \cdot 1^{*}$ \\
$10 \cdot 0$ & 6 & $2(33 \%)$ & $0 \cdot 5 \pm 0 \cdot 5^{*}$ & $19 \cdot 8 \pm 2 \cdot 7^{*}$ \\
$20 \cdot 0$ & 8 & $6(75 \%)$ & $5 \cdot 2 \pm 1 \cdot 6^{*}$ & $25 \cdot 3 \pm 1 \cdot 1^{*}$ \\
\hline
\end{tabular}

* Significantly different from control.

range for control rabbits, and thus there was no indication of any inhibition of LH release.

\section{ANDROGENIC EFFECTS IN RATS}

The androgenicity of these compounds was not specifically examined, but the results of the experiments shown in Tables 6 and 7 provide no evidence for any such effect. Increasing doses of I.C.I. 46,474 produced no significant increase but only decreases in the weight of the accessory organs in male rats. The same is true for I.C.I. 47,699 .

\section{ANTI-ANDROGENIC EFFECTS IN RATS}

These were evaluated in castrated immature male rats treated with testosterone propionate either alone or in combination with graded doses of I.C.I. 46,474 
(Table 10). Although the figures do not reach the level of statistical significance $(P=0.05)$, they suggest that I.C.I. 46,474 interferes directly with the action of androgen on the prostate. The effect is small and independent of the dose over the range of $0 \cdot 1$ to $10 \mathrm{mg} / \mathrm{kg} /$ day, but is possibly sufficient to account for the effect of the compound on the weight of this organ in intact male rats (Table 6). On the other hand, the response of the seminal vesicles to androgenic stimulation was quite unaffected in the castrate by the doses of I.C.I. 46,474 given. The effect of still higher doses $(25 \mathrm{mg} / \mathrm{kg} / \mathrm{day}$ and above) which cause a significant loss in weight of this gland in intact animals remains to be determined.

TABLE 10

EFFECT OF I.C.I. 46,474 ON THE RESPONSE OF ACGESSORY ORGANS TO ANDROGEN IN CASTRATE MALE RATS (EIGHT/GROUP)

\begin{tabular}{|c|c|c|c|c|c|c|}
\hline \multicolumn{2}{|c|}{ Daily dose of } & \multirow{3}{*}{$\begin{array}{c}\text { Final } \\
\text { body weight } \\
(\mathrm{g})\end{array}$} & \multicolumn{4}{|c|}{ Weights (mg) of: } \\
\hline \multirow{2}{*}{$\begin{array}{c}\text { Testosterone } \\
\text { propionate } \\
(\mu \mathrm{g} / \text { rat })\end{array}$} & \multirow{2}{*}{$\begin{array}{l}\text { I.C.I. 46,474 } \\
\quad(\mathrm{mg} / \mathrm{kg})\end{array}$} & & \multicolumn{2}{|c|}{ Ventral prostate } & \multicolumn{2}{|c|}{ Seminal vesicles } \\
\hline & & & Absolute & Relative & Absolute & Relative \\
\hline $\begin{array}{r}0 \\
25 \\
25 \\
25 \\
25\end{array}$ & $\begin{array}{l}0 \\
0 \\
0 \cdot 1 \\
1 \cdot 0 \\
10 \cdot 0\end{array}$ & $\begin{array}{l}65 \cdot 6 \\
57 \cdot 9 \\
69 \cdot 5 \\
62 \cdot 5 \\
63 \cdot 6\end{array}$ & $\begin{array}{l}10 \cdot 0 \\
42 \cdot 0 \\
37 \cdot 6 \\
35 \cdot 4 \\
35 \cdot 6\end{array}$ & $\begin{array}{l}15 \cdot 3 \\
72 \cdot 6 \\
54 \cdot 2 \\
56 \cdot 7 \\
56 \cdot 0\end{array}$ & $\begin{array}{r}4 \cdot 2 \\
28 \cdot 9 \\
32 \cdot 8 \\
32 \cdot 5 \\
33 \cdot 1\end{array}$ & $\begin{array}{r}6 \cdot 4 \\
49 \cdot 9 \\
47 \cdot 2 \\
52 \cdot 0 \\
52 \cdot 0\end{array}$ \\
\hline
\end{tabular}

TABLE 11

EFFECTS OF I.C.I. 46,474 ON THE OESTROUS CYCLE OF THE RAT

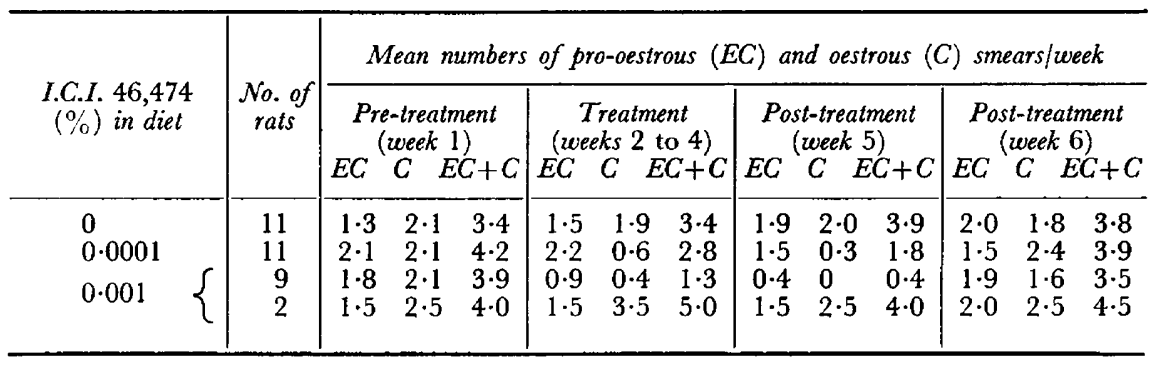

EFFECTS ON THE OESTROUS GYCLE OF THE FEMALE RAT

In normally cycling rats, I.C.I. 46,474 at $0.0001 \%$ in the diet did not abolish the oestrous cycle, but prevented the appearance of fully cornified smears (Table 11). At the higher level $0.001 \%$, extended periods of di-oestrus were observed in nine out of eleven rats, while the remaining two showed continuously cornified smears for periods of more than 7 days. In both groups the numbers of pro-oestrous and oestrous smears fell sharply during the 7 days following withdrawal of the compound before returning to normal in the second week post-treatment. 
ACUTE LETHALITY FOR MICE

The $\mathrm{LD}_{50}$ and its $95 \%$ confidence limits were 3100 (2610 to 3690$) \mathrm{mg} / \mathrm{kg}$ and $270(201$ to 362$) \mathrm{mg} / \mathrm{kg}$ for the oral and intraperitoneal routes respectively.

\section{EFFECTS ON CHOLESTEROL BIOSYNTHESIS IN RATS}

I.G.I. 46,474 at $0.01 \%$ in the diet was found to decrease cholesterol in the serum in male and female rats to $71 \%$ and $76 \%$ respectively of the control values, without affecting cholesterol in the liver. The mean effect, overall, on the desmosterol content of serum and liver (i.e. on the 'ratio' referred to under 'Materials and Methods', p. 105) was a slight but significant fall in the females and no significant change in the males.

TABLE 12

COMPARATIVE BIOLOGICAL EFFECTS OF I.G.I. 46,474, I.C.I. 47,699 AND DIENOESTROL

\begin{tabular}{|c|c|c|c|c|c|c|c|}
\hline \multirow{3}{*}{ Compound } & \multicolumn{7}{|c|}{ Median effective doses ( $\mathrm{mg} / \mathrm{kg} /$ day $)$} \\
\hline & \multicolumn{2}{|c|}{ Lethal } & \multirow{2}{*}{$\underset{\text { oral }}{A I}$} & \multirow{2}{*}{$\begin{array}{c}V C \\
\text { oral* }\end{array}$} & \multirow{2}{*}{$\underset{\text { oral }}{V C}$} & \multirow{2}{*}{$\underset{\text { oral* }}{P I}$} & \multirow{2}{*}{$\underset{\text { oral }}{\text { IO }}$} \\
\hline & $\overline{\text { Oral }}$ & $i . p . \dagger$ & & & & & \\
\hline I.C.I. 46,474 & 3100 & 270 & 0.03 & $41 \cdot 0$ & 1.40 & c. $25 \cdot 0$ & 0.25 \\
\hline I.C.I. 47,699 & - & - & $0 \cdot 28$ & $0 \cdot 18$ & $7 \cdot 5$ & c. 0.5 & $>1.0$ \\
\hline Dienoestrol & - & - & 0.02 & 0.004 & - & $<0.01$ & c. $0 \cdot 1$ \\
\hline
\end{tabular}

* Experiments with rats.

$\uparrow$ Experiments with mice.

AI, Anti-implantation; VC, vaginal cornification; PI, pituitary inhibition; IO, Inhibition of ovulation.

\section{DISGUSSION}

The median effective doses of I.C.I. 46,474 and 47,699 and dienoestrol in respect of several parameters of biological effect are shown for comparison in Table 12. A striking difference is immediately apparent between the balance of properties of I.C.I. 46,474 and those of its cis-isomer, I.C.I. 47,699. The latter resembles the conventional oestrogen, dienoestrol, although it is considerably less potent in all respects. I.C.I. 46,474 is distinguished by its extreme efficacy, relative to its oestrogenic potency, in preventing implantation in rats. It is also moderately effective in inhibiting ovulation in this species, although it has little effect on pituitary gonadotrophic function in the male. As already shown (Table 5, Text-figs. 2 and 3), it is quite effective in counteracting exogenous oestrogen. The reason for its relatively high oestrogenic potency in mice is as yet obscure. It is noteworthy that, in this species, it is in fact more active than the cis-isomer (about $5 \times$ ), whereas in rats it has only a fraction (about $1 / 200$ ) of the activity of the latter in inducing vaginal cornification.

It seems unlikely that the effect of I.C.I. 46,474 in preventing implantation, at least with doses of the order of the minimal effective dose, is due to oestrogenic 
action or pituitary suppression. In both rats and mice the doses required to terminate early pregnancy are lower than those for vaginal cornification. In rats, the ratio is large; in mice, very much smaller. On the other hand, as shown in Tables 1 and 4, the conventional oestrogen, dienoestrol-or for that matter I.C.I. 47,699-requires to be given in a higher dose to produce an anti-fertility effect in rats than that needed for vaginal cornification. Moreover, as shown in Table 1, the variation in effectiveness, according to the day of administration, of single doses of I.C.I. 46,474 in preventing implantation in rats is of a completely different pattern from that of dienoestrol. Dienoestrol is most effective when given on Day 2 or 3 of pregnancy and is still effective on Day 5 . In this it resembles oestrone, given subcutaneously (Edgren \& Shipley, 1961). I.C.I. 46,474 , however, is most effective on Day 4 and without effect if given on Day 5 in a relatively enormous dose. For these reasons it is improbable that the interference with pregnancy produced by the compound can be accounted for by its oestrogenic action.

It is also unlikely to be due to interference with pituitary function. In experiments in intact male rats, very large doses of I.C.I. 46,474 are required to cause significant reduction in relative weight of the accessory sexual organs (Table 6). The relatively greater efficacy of I.C.I. 47,699 in this respect is evident from Table 7. In puberal females, ovulation is inhibited with relatively low doses of I.C.I. 46,474 (Table 8), but even these are several times in excess of the median effective dose for inhibition of implantation. Moreover, it is not certain that this inhibition of ovulation is mediated by an effect on pituitary function. The result in males suggests, rather, a direct action on the ovary and this possibility has not yet been excluded.

The fact that I.C.I. 46,474 is maximally effective in preventing implantation in rats when given on Day 4 of pregnancy, and inactive on Day 5, suggests that it acts by interfering with some event which has occurred by the 5th day and upon which implantation critically depends. It has been shown (Psychoyos, 1960; Shelesnyak, Kraicer \& Zeilmaker, 1963; Zeilmaker, 1963) that, in pregnant rats, implantation of the blastocysts can be completely prevented by ovariectomy up to mid-day on the 4th day. These authors are agreed that a release of oestrogen from the ovary, necessary to induce implantation, occurs between noon and midnight on that day. I.C.I. 46,474 has anti-oestrogenic properties as indicated by inhibition of the action of exogenous oestrogen on the vaginal epithelium and uterine weight, and these properties are manifest with doses of about the same order as those required to prevent implantation (Table 5, Text-fig. 2). It is suggested that the compound interferes with implantation by counteracting this oestrogen-release. Evidence for a like interpretation of the action of U-11555A and U-11100A on implantation has already been cited (Duncan \& Lyster, 1963; Duncan \& Forbes, 1965). In view of its similarity to these compounds, both in structure and in the overall pattern of its endocrine activity, it seems reasonable to suppose that it may affect that process in a similar way. We have shown (unpublished) that, like U-11555A and U-11100A (Duncan \& Forbes, 1965) and clomiphene (Staples, 1966), I.C.I. 46,474 does not destroy blastocysts in the uterus in doses which prevent implantation. We have also demonstrated that it is possible, with oestrogen, to 
induce implantation in rats in which this process has been suspended by the administration of I.C.I. 46,474 on the 4 th day of pregnancy in a minimal effective dose. These and other experiments in the same context will be reported in detail elsewhere.

The mechanism of action of I.C.I. 46,474 as an anti-oestrogen remains to be considered. It may displace oestrogen from serum binding sites-thus interfering with its transport-or prevent its access to or retention by receptor sites in target organs and thus interfere with its action on these organs. Roy, Mahesh \& Greenblatt (1964) have found that uptake of tritiated oestradiol by the uterus and pituitary of rats is decreased by pre-treatment with clomiphene, and Jacobson, Smith, Colucci \& Jensen (1964) have shown that U-11100A and U-11555A prevent steroid retention in responsive target organs (e.g. the uterus, the vagina and the pituitary). Experiments in this connection with I.C.I. 46,474 are in hand.

The $\mathrm{LD}_{50}$ (in mice) of I.C.I. 46,474 is very high relative to doses which affect the endocrine system. Triparanol (MER-29), a member of a related series of compounds, blocks cholesterol synthesis and has been used clinically to lower serum-cholesterol. Cutaneous ichthyosis and loss of hair have been reported in patients taking this drug and in some, cataract subsequently developed (Perry, Winkelmann, Achor \& Kirby, 1962; Achor, Christensen, Berge \& Mason, 1963). These toxic effects may be due to an accumulation in the affected tissues of sterol precursors of cholesterol. In rats given Triparanol, roughness and scaliness of the skin has been observed, associated with increased levels in the skin of desmosterol and lanosterol (Gaylor, 1963; Horlick \& Avigan, 1963) : accumulation of desmosterol also occurs in serum and liver, while cholesterol levels fall (Frantz, Mobberley \& Schroepfer, 1960; Avigan, Steinberg, Thompson \& Mosettig, 1960). Compounds of the present series were therefore examined for effects on cholesterol biosynthesis. I.G.I. 46,474 did not increase the desmosterol content of the serum and liver, although the cholesterol content of the serum was reduced.

\section{ACKNOWLEDGMENTS}

We are indebted to Dr Dora N. Richardson for the preparation of I.C.I. 46,474 and 47,699 and to Dr G. R. Bedford for determining their configuration. We should like to thank Mr J. M. Thorp for advice on the determination of desmosterol, and Mrs Audrey Smith, Mrs Barbara E. Valcaccia, Miss Rosemary Chester, Miss Patricia H. Maxwell and Mrs Anne Barton for technical assistance.

\section{REFERENCES}

Agell, L. L., LeVy, B. B., Brodie, B. B. \& Kendall, F. E. (1952) A simplified method for the estimation of total cholesterol in serum and demonstration of its specificity. 7. biol. Chem. 195, 357.

Achor, R. W. P., Christensen, N. A., Berge, K. G. \& Mason, H. L. (1963) Treatment of hypocholesteremia with Triparanol and comparison with nicotinic acid. Proc. Staff Meet. Mayo Clin. $38,32$.

Avigan, J., Steinberg, D., Thompson, M. J. \& Mosettig, E. (1960) The mechanism of action of MER-29. Prog. cardiovasc. Dis. 2, 525.

Avigan, J., Steinberg, D., Vroman, H. E., Thompson, M. J. \& Mosettig, E. (1960) Studies of cholesterol biosynthesis: I. The identification of desmosterol in serum and tissues of animals and man treated with MER-29. 7. biol. Chem. 235, 2123. 
Connerty, H. V., Briggs, A. R. \& Eaton, E. H. (1961) Simplified determination of the lipid components of blood serum. Clin. Chem. 7, 37.

Cooper, J. R., Axelrod, J. \& Brodie, B. B. (1954) Inhibitory effects of $\beta$-diethylaminoethyl diphenylpropylacetate on a variety of drug metabolic pathways in vitro. J. Pharmac. exp. Ther. 112, 55.

Duncan, D. B. (1955) Multiple range and multiple ' $F$ ' tests. Biometrics, $11,1$.

Duncan, G. W. \& Forbes, A. D. (1965) Blastocyst survival and nidation in rats treated with oestrogen antagonists. 7. Reprod. Fert. 10, 161.

Duncan, G. W. \& Lyster, S. C. (1963) Effect of a diphenylindene derivative (U-1 1555A) on blastocyst survival in utero. Fert. Steril. 14, 565.

Duncan, G. W., Lyster, S. C., Clark, J. J. \& Lednicer, D. (1963) Antifertility activities of two diphenyl-dihydronaphthalene derivatives. Proc. Soc. exp. Biol. Med. 112, 439.

Duncan, G. W., Stucki, J. C., Lyster, S. C. \& Lednicer, D. (1962) An orally effective mammalian antifertility agent. Proc. Soc. exp. Biol. Med. 109, 163.

Edgren, R. A. \& Shipley, G. C. (1961) A quantitative study of the termination of pregnancy in rats with estrone. Fert. Steril. 12, 178.

Emmens, C. W. (1941) Precursors of oestrogens. 7. Endocr. 2, 444.

Frantz, I. D., JR., Mobberley, M. L. \& Schroepfer, G. J., JR. (1960) Effects of MER-29 on the intermediary metabolism of cholesterol. Prog. cardiovasc. Dis, $2,511$.

GAYLOR, J. L. (1963) Biosynthesis of skin sterols. II. Reduction of $\Delta^{\mathbf{2 4}}$-unsaturated sterols of rat skin. Archs Biochem. Biophys. 101, 108.

Holtkamp, D. E., Greslin, J. G., Root, C. A. \& Lerner, L. J. (1960) Gonadotrophin-inhibiting and anti-fertility effects of chloramiphene. Proc. Soc. exp. Biol. Med. 105, 197.

Horlick, L., \& Avigan, J. (1963) Sterols of skin in the normal and triparanol-treated rat. 7. lipid Res. $4,160$.

Jaconson, H. I., Smrth, S., Colucci, V. \& Jensen, E. V. (1964) Effect of anti-uterotrophic agents on the uptake of estradiol by rat tissues. Proceedings Endocrine Society, San Francisco, California, p. 38.

Litchfield, J. T., JR. \& WiLcoxon, F. (1949) A simplified method of cvaluating dose-effect experiments. 7. Pharmac. exp. Ther. 96, 99.

Paget, G. E., Walpole, A. L., \& Richardson, D. N. (1961) Non-steroid inhibitors of pituitary gonadotrophic function. Nature, Lond. 192, 1191.

Perry, H. O., Winkelmann, R. K., Achor, R. W. P. \& Kirby, T. J., JR. (1962) Side effects of Triparanol therapy. Am. F. med. Sci. 244, 556.

Psychoyos, A. (1960) Nouvelle contribution à l'étude de la nidation de l'oeuf chez la ratte. C. r. hebd. Séanc. Acad. Sci., Paris, 251, 3073.

Richardson, D. N. (1965) U.K. Patent Specification No. 1013907.

Robson, J. M., Schönberg, A. \& Fahim, H. A. (1938) Duration of action of natural and synthetic oestrogens. Nature, Lond. 142, 292.

Roy, S., Mahesh, V. B. \& Greenblatt, R. B. (1964) Effects of clomiphene on the physiology of reproduction in the rat. III. Inhibition of uptake of radioactive oestradiol by the uterus and the pituitary gland of immature rat. Acta endocr., Copenh. 47, 669.

Shelesnyak, M. C., Kraicer, P. F. \& Zeilmaker, G. H. (1963) Studies of the mechanism of decidualization. I. The oestrogen surge of pseudopregnancy and progravidity and its role in the process of decidualization. Acta endocr., Copenh. 42, 225.

Staples, R. E. (1966) Effect of clomiphene on blastocyst nidation in the rat. Endocrinology, 78, 82.

Zeilmaker, G. H. (1963) Experimental studies on the effects of ovariectomy and hypophysectomy on blastocyst implantation in the rat. Acta endocr., Copenh. 44, 355. 